\title{
The Effect of Gender on Career Progression: A Conceptual Model
}

\author{
Ranitha Sachinthana Weerarathna ${ }^{1} \&$ Suchira. Hapurugala ${ }^{2}$ \\ ${ }^{1}$ Senior Lecturer, Department of Business Management, Faculty of Business, Sri Lanka Institute of Information \\ Technology, Malabe, Sri Lanka \\ ${ }^{2}$ Chartered Institute of Personnel Management, Sri Lanka \\ Correspondence: Ranitha Sachinthana Weerarathna, Department of Business Management, Faculty of Business, \\ Sri Lanka Institute of Information Technology, Malabe, Sri Lanka. E-mail: ranitha.w@sliit.lk
}

Received: May 5, 2019

Accepted: May 28, 2019

Online Published: May 31, 2019

doi:10.5539/ijbm.v14n7p23

URL: https://doi.org/10.5539/ijbm.v14n7p23

\begin{abstract}
This paper attempts to develop a conceptual model to test the effect of gender on career progression. In the Sri Lankan context, there is a perception that there is difference between female oriented jobs and male oriented jobs. When economic statistics and company related details are considered, it can be surmised that there is an impact of gender on career progression. This research paper proposes definitions for variables related to career progression and career advancement in organizations. Based on these definitions and on an extensive literature survey, the current researchers will develop a conceptual framework to test the effect of gender on career progression.
\end{abstract}

Keywords: gender, career progression, glass ceiling

\section{Introduction}

In the contemporary world, women are breaking the glass ceiling and achieving targets, where many believed that these targets could only be achieved by men. For example, Jayanthi Kuru-Utumpala was the first Sri Lankan to summit Mount Everest, and Sri Lankan scientist, Hasini Jayathilaka, has been identified by the Forbes 30 under 30 index as one of the best innovators and entrepreneurs in the world with her groundbreaking discovery, Two Sri Lankan girls won the 2nd runner up trophy for the International Women's Extreme 4 X 4 Challenge, but still the corporate world thinks twice when handing over tasks and responsibilities to a female. The percentage of women becoming only housewives has decreased significantly in recent years in Sri Lanka (Department of Census and Statistics, 2014). According to the current researcher, the percentage of employed women has increased mainly as a result of free education, the open economy, financial needs rising due to competitive socio economic development, freedom from war, and because every individual is entitled to enjoy basic human rights in Sri Lanka, without discrimination.

Many women in Sri Lankan organizations have achieved their objectives by overcoming many obstacles and simultaneously maintaining the appropriate work-life balance. Although women and men perform many of the same tasks at work, there is a tendency for only men to be promoted due to gender biases in industries, in working environments and due to conservative beliefs about women. Only the garment industry, and the nursing and teaching professions can be considered as female dominated work fields in Sri Lanka. But even here, the senior levels of management in these industries are dominated by men. This research study analyzes the impact of gender on career progression at ABC Motor Engineering PLC in Sri Lanka. The researcher further explores the barriers to achieving gender equality in the working environment and in career progression, along with the general objective mentioned earlier.

Most research studies related to gender in corporate organizations have examined Gender Equity, Gender Equality and Gender Inequality in terms of Performance, Job Satisfaction, Work Life Balance and Organizational Culture. The current researcher selected the above organization for analysis because it is a male-dominated industry.

\subsection{Statement of Research Problem}

Doug Harris, CEO of the Kaleidoscope Group once said "You could have eight people look at something, and 
the way they see it will be unique based on who they are, the way they see the world, their generation and their GENDER". Gender diversity, gender equality or gender equity at the workplace are some of the global topics that are continuously discussed and debated where females are consistently under-represented in management teams (Skroupa, 2016).

The Department of Census and Statistics (2017) stated that the aggregate employed population of Sri Lanka in 2017 was $95.8 \%$ according to Employment Statistics by Gender. Of the aggregate employed population, 97.1\% are males and 93.5\% are females (Department of Census and Statistics, 2017).

Table 1. Summary statistics on labour force characteristics

\begin{tabular}{llll}
\hline & Total & Male & Female \\
\hline Population (18 years \& over) & $14,808,549$ & $6,779,991$ & $8,028,558$ \\
Labour force in this age group & $8,506,937$ & $5,392,868$ & $3,114,069$ \\
Labour force participation rate & 57.4 & 79.5 & 38.8 \\
Employed population & $8,161,206$ & $5,245,334$ & $2,915,872$ \\
Employment rate & 95.9 & 97.3 & 93.6 \\
Unemployment rate & 4.1 & 2.7 & 6.4 \\
\hline
\end{tabular}

Source: Labour Force Survey - Annual Report 2017.

According to Table 2, most females are not employment due to their household chores, and the percentage of housewives is $60 \%$. Sixteen percent of women are not employed because they are retired, and fifteen percent are fully involved in their academic studies.

Table 2. Reasons for being economically inactive by gender

\begin{tabular}{llll}
\hline & & Gender & \\
& Total & Male & Female \\
\hline All Economically Inactive & 100.0 & 100.0 & 100.0 \\
Engaged in studies & 21.6 & 39.6 & 15.4 \\
Engaged in housework & 46.3 & 4.9 & 60.5 \\
Retired/Old age & 20.3 & 32.9 & 16.0 \\
Physically illness/Disabled & 8.0 & 15.9 & 5.3 \\
Other & 3.8 & 6.7 & 2.8 \\
\hline
\end{tabular}

Source. Labour Force Survey - Annual Report 2017

Mirroring the national level statistics, the selected company has many more male employees than female employees. The numbers are a hundred and seventy three (173) female employees out of a thousand eight hundred and one (1801) total employees at ABC Motor Engineering PLC.

The question that the researcher wishes to pose is "does gender really impact on career progression at workplaces?" Women at workplaces, especially those in male dominated industries, will be highly affected by gender considerations during career progression. The researcher believes that twenty - first - century career focused women are good at working while balancing their personal lives as well. Most working women have achieved some kind of career goals hitherto thought to be beyond their reach, showing that women are not unable to take up responsibilities or challenges. This view directly challenges gender stereotyping. The current researcher explores this problem by analyzing the results obtained from the study done at $\mathrm{ABC}$ Motor Engineering PLC in Sri Lanka, since the main reasons for female attrition in the organization according to the last financial year exit interview summary was obtaining better job opportunities and family or personal commitments. The female attrition ratios of the financial years 2014/2015, 2015/2016, 2016/2017 and 2017/2018 are $12.66 \%, 17.68 \%, 10.88 \%$ and $14.97 \%$, respectively.

\section{Practical Relevance of the Study}

Men and women in a workplace differ in their attitudes and behavioral responses to a situation. However, here should not be gender discrimination when empowering employees to undertake responsibilities in relation to their jobs. The main purpose of this research is to obtain an insight into the current perceptions about career 
progression in relation to the glass ceiling in corporate organizations in Sri Lanka.

The results of this research carried out on the impact of the glass ceiling on career progression at ABC Motor Engineering will be important to this organization as they have recently launched their women's network that gives prominence to gender diversification. The research study will also enable the organization to introduce several process related and procedural improvements that will increase gender diversification by creating equal career opportunities for female employees, which will, in turn, help the company to grow. This will guide management in formulating future management strategies for their Human Resources department as well as for other areas related to career progression in the organization. The researcher, as a female employee in this organization who stands for equity, considers this research to be a source of great encouragement to existing female employees towards improving their careers by promoting a better and fairer work environment while attracting talented female employees to the organization from outside.

This study would also benefit future researchers as a point of reference when conducting studies related to the glass ceiling or to career progression. Also, they can use this research to locate data, to familiarize themselves with the methods used for analysis and the methods used to collect data and to gain knowledge about how a gender related research study should be conducted in a satisfactory manner.

\section{Literature Review}

A number of research publications over the past years have drawn attention to career progression in relation to professions and family related matters (e.g. Windsor, 2004; Valcour and Tolbert, 2003; Kirchmeyer, 2002). There are a number of articles, journals and other works of academic research that have found that there is a significant increase in the available roles for women in the workplace, both nationally and internationally (Jogulu \& Wood, 2011). As a result of the increasing participation of women in the labor force all over the world, the number of female employees taking up managerial positions has also increased (Jogulu \& Wood, 2011). For example, in the USA in 2010, the percentage of managerial and professional jobs held by women was 51.5 percent (Jogulu \& Wood, 2011); in Australia, 44.6 percent of managerial and professional job roles were occupied by women in 2010 (Jogulu \& Wood, 2011); and in Canada, women held 36.8 percent of managerial and professional specialist positions (Jogulu \& Wood, 2011). These figures are significant compared to those of the 1960s and 1970s, where only 16 per cent of managerial positions were held by women in the USA (Powell, 1999).

The research conducted by Jogulu and Wood (2011) on Women managers' career progression; An Asia Pacific perspective, mentions that there is a global trend of women failing in managerial careers more than men, due to significant challenges and barriers faced by these women in their middle-management careers, that hinder their further progression into senior roles (Jogulu \& Wood, 2011).

\subsection{Definitions of Key Concepts and Explanations}

The concept of the glass ceiling refers to "artificial barriers to the advancement of women and minorities," and those barriers represent "discrimination" (The federal glass ceiling commission, 1995). The glass ceiling is unseen and unreachable and keeps minorities and women from climbing the corporate ladder, regardless of their qualifications, experience or achievements (The federal glass ceiling commission, 1995). These descriptions of and elaborations on the glass ceiling reveal that there is job inequality and labor market discrimination, apart from labor market inequality.

Usually, glass ceiling inequality means that gender or racial difference, is used as weapon of discrimination in education, training, volunteer work or leisure activities (Cotter, Hermsmen, Ovadia \& Vanneman, 2001).

\subsection{Gender Diversification and Organizational Performance}

Women's economic opportunity (Women's Economic Opportunity Index, WEOI) is defined "as a set of laws, regulations, practices, customs and attitudes that allow women to participate in the workforce under conditions roughly equal to those of men" (Economist Intelligence Unit, 2012).However, there is a drastic different between the economic opportunities available in developing countries when compared to those in developed countries (Hayashi, Vermeulen \& Knoben, 2016).

There are four benefits of gender diversity for innovation in organizations, according to research conducted on Gender Diversity and Innovation: The Role of Women's Economic Opportunity in Developing Countries by Hayashi, Vermeulen and Knoben, 2016.

The first benefit is the potential, that different attributes, perspectives and knowledge in gender diversified organizations, for positive innovation when men and women share their experience and career trajectories in similar positions but with different viewpoints in accordance with their genders as men and women, made 
distinct by their unique human and social capital backgrounds (Lin \& Singh, 2008).

The second benefit of gender diversity can be identified as the increased and diversified knowledge pool outside the organization that gender diversity provides access to and contributes to, and the contacts made with different networks, through which the organization can sustain a rich pool of external information as a baseline for innovative activities in the organization (Milliken \& Martins, 1996). Further, gender diversification helps to identify diverse customer needs and market trends which foster an organization to develop new strategies in line with customers' expectations.

The third one is cognitive abilities, and it is believed that the genders are different as far as their cognitive abilities are concerned. Cognitive conflict and expression of viewpoints are inherently different in men and women when they face unexpected situations or complex problems at work.

Fourthly, women are more comfortable in an open and flexible work atmosphere that includes an open door policy focusing on interpersonal relationships to share ideas and knowledge than men, and this will benefit the interactive nature of the organization. This open door policy is more apparent in the leadership styles of female managers than in their male counterparts, and this reveals the inner transformational leadership style of women.

\subsection{Career Progression}

There is a major distinction between career growth or career progression and career development. Career progression means the organizational hierarchical ladder and career development means the responsibilities of employees to enhance or develop their careers on their own (Thomas, 2012).

Career progression involves moving to higher positions, functioning strategically, and focusing on set goals when moving up the corporate ladder, while career development involves an integral improvement in skills and talent, specifically by improving skill to expertise, and a transformative mindset that focuses on how to achieve goals (Brighter Monday, 2018).

Basically, career progression or growth involves set stages and goals in the field of work that an employee must work hard towards. It is a form of promotion from one role to a higher one based on performance and experience. Career development, on the other hand, is the personal transformation that comes about through training and development, learning and experience, that helps to achieve goals in the new role (Brighter Monday, 2018).

A review of the literature highlights a key questions and theories useful for exploring the question in this research study. Davey et al., (2005) mentioned that women who take a career break face lack of promotional possibilities and reduced careers which is linked in the literature to the acquisition of 'human capital'. Also, the research conducted by Catherine \& Pine (2003) found that there is no huge difference between the obstacles faced or the factors that impact on career progression in men and women. The extant literature reviews have failed to generate consistent results to prove that there is an association between the glass ceiling and career progression, apart from identifying the barriers that women have to surmount in their careers when compared to those that men have to deal with.

\section{Proposed Conceptual Framework}

The suggested conceptual framework is logically developed based on previous research studies. Two variables were considered to test the relationship between the glass ceiling and career progression. As one of the objectives of the study is to identify the association between the glass ceiling and career progression, career progression can be labeled as the dependent variable and the glass ceiling as the independent variable.

\section{Conclusions}

The main purpose of this study is to develop a conceptual model to examine the effect of gender on career progression. With the support of previous studies, the researchers were able to develop a conceptual model to examine the effect of gender on career progression. Future researchers will be able to test the model in any kind of organization and examine the effect of gender on career progression in that context. Further, future researchers can extend this model by exploring the effects of moderating variables on the relationship between the glass ceiling and career progression.

\section{References}

Cotter, D., Hermsen, J., Ovadia, S., \& Vanneman, R. (2001). The Glass Ceiling Effect (Doctoral dissertation).

Cotter, D., Hermsen, J., Ovadia, S., \& Vanneman, R. (2018). The Glass Ceiling Effect (The Academic Level). University of Maryland.

Department of Census and Statistics. (2014). Labour Force Survey - Annual Report 2014. 
Department of Census and Statistics. (2017). Labour Force Survey - Annual Report 2017.

Hayashi, D., Vermeulen, P., \& Knoben, J. (n.d.). Gender diversity and innovation: The role of Women's economic opportunity in developing countries (Working paper).

Jogulu, U., \& Wood, G. (2011). Career Progression of Managers: An Asia-Pacific Perspective (Doctoral dissertation, Deakin University).

Jogulu, U., \& Wood, G. (2011). Women managers' career progression: an Asia Pacific perspective. Gender in Management: An International Journal, 26(8), 590-603. https://doi.org/10.1108/17542411111183893

Kirchmeyer C. (2002), Gender Differences in Managerial Careers: Yesterday, Today, and Tomorrow, Journal of Business Ethics, 37(1), 5-24

Milliken, F., \& Martins, L. (1996). Searching for Common Threads: Understanding the Multiple Effects of Diversity in Organizational Groups. The Academy of Management Review, 21(2), 402.

Powell, G. N. (1999). Handbook of gender \& work. Thousand Oaks, CA: Sage Publications.

Thomas, R. (2018, June 21). What Is the Difference Between Career Growth and Career Development? Retrieved December $\quad 02, \quad 2018, \quad$ from https://www.workforce.com/2012/12/03/what-is-the-difference-between-career-growth-and-career-develop ment/

Valcour, P. M., \& Tolbert, P. (2003). Gender, family and career in the era of boundarylessness: Determinants and effects of intra- and inter-organizational mobility. The International Journal of Human Resource Management, 14(5), 768-787.

\section{Copyrights}

Copyright for this article is retained by the author(s), with first publication rights granted to the journal.

This is an open-access article distributed under the terms and conditions of the Creative Commons Attribution license (http://creativecommons.org/licenses/by/4.0/). 